\title{
Prehispanic Aymara expansion, the Southern Altiplano and San Pedro de Atacama
}

DAVID L. BRowman ${ }^{1}$

\section{Introduction}

Aymara speakers are intrusive into the Southern Peruvian Coast and Northern Chilean coast during Tiwanaku Period V, with the establishment of mitmaquna settlements. Trade can be dated much earlier. These developments influenced the development of the altiplano-coast interrelations in the Late Period (AD 1000-1450). However the Southern Bolivian Altiplano, Northwest Argentine puna and Jujuy area, and the Chilean Region II polities were much more powerful and independent than we usually have credited them with being.

To illustrate the interactions particularly between the Southern Bolivian Altiplano and the San Pedro de Atacama Region, I will develop a four-stage argument. First I want to use linguistic data to outline a three part Aymara split, which is related to historical development. The speakers of two of the different dialects relate in different ways to the North Chilean cultures.

These Aymara folk, particularly in the Southern Bolivian Altiplano, lived in areas where it is too high and cold, and too arid to practice much agriculture beyond some Chenopodium grain and various tubers. Herding of camelids, and more importantly trade caravans, were an essential part of the subsistence strategy of these Southern Altiplano folk. A brief review of Southern Bolivian trade networks will emphasize this aspect. Although the more important argument focuses upon the late chiefdoms of $\mathrm{AD}$ 1000-1450, we must understand to what extent the previous Tiwanaku federation influenced the Southern Bolivian and Chilean groups to perceive any shifts in alliances. Thus there is a series of arguments which preface the final hypothesis development of the kinds of interaction which might have existed between the Southern Altiplano folk (the makers of

1 Department of Anthropology Washington University, St. Louis, Missouri 4 63130, ESTADOS UNIDOS.
Huruquilla, Yura, Llamita, or Chullpa wares, etc.) and the Chilean coastal groups. ${ }^{2}$

\section{Development of three Aymara dialects/ divisions}

In Peru, the split between cusqueño quechua vs. other dialects of quechua has been a very powerful tool in helping to understand the expansion of the Inca empire as contrasted to preincaic quechua speaking areas. There are now at least seven major dialects of quechua identified, and linguists and archaeologists have begun to be able to correlate specific quechua dialects with specific archaeological culture and historical empires (for example, defining the spread of the Wari empire north with the spread of quechua IB).

This now can be expanded to Aymara dialects in Southern Peru/Bolivia/Northern Chile. The starting point for the analysis was a dissertation by Briggs (1976). She noted that the linguistic difference between the Northern Altiplano dialect of Aymara and the Central Southern Altiplano Aymara dialect "implied a social/political split at some time in the past". Following up on her work, I began collecting information on the location of Aymara speakers in the $16^{\text {th }}$ and $17^{\text {th }}$ century, to attempt to define the locations of the Aymara dialects at the time of the Inca conquest.

Briggs referred to three different clusters of Aymara speaking groups, a Northern, Southern and intermediate group. She did not feel able to make a temporal distinction for which group was earlier or later other than to suggest that the intermediate group, with traits common in part both to the Southern and Northern clusters, might be somewhat later In origin.

Archaeology allows us to develop what appears to be a complete scenario for the division of these three Aymara groups. In Figure 1, I have drawn the apparent

\footnotetext{
2 Nota del Editor: Este trabajo no fue discutido en el Simposio debido a la ausencia del autor.
} 


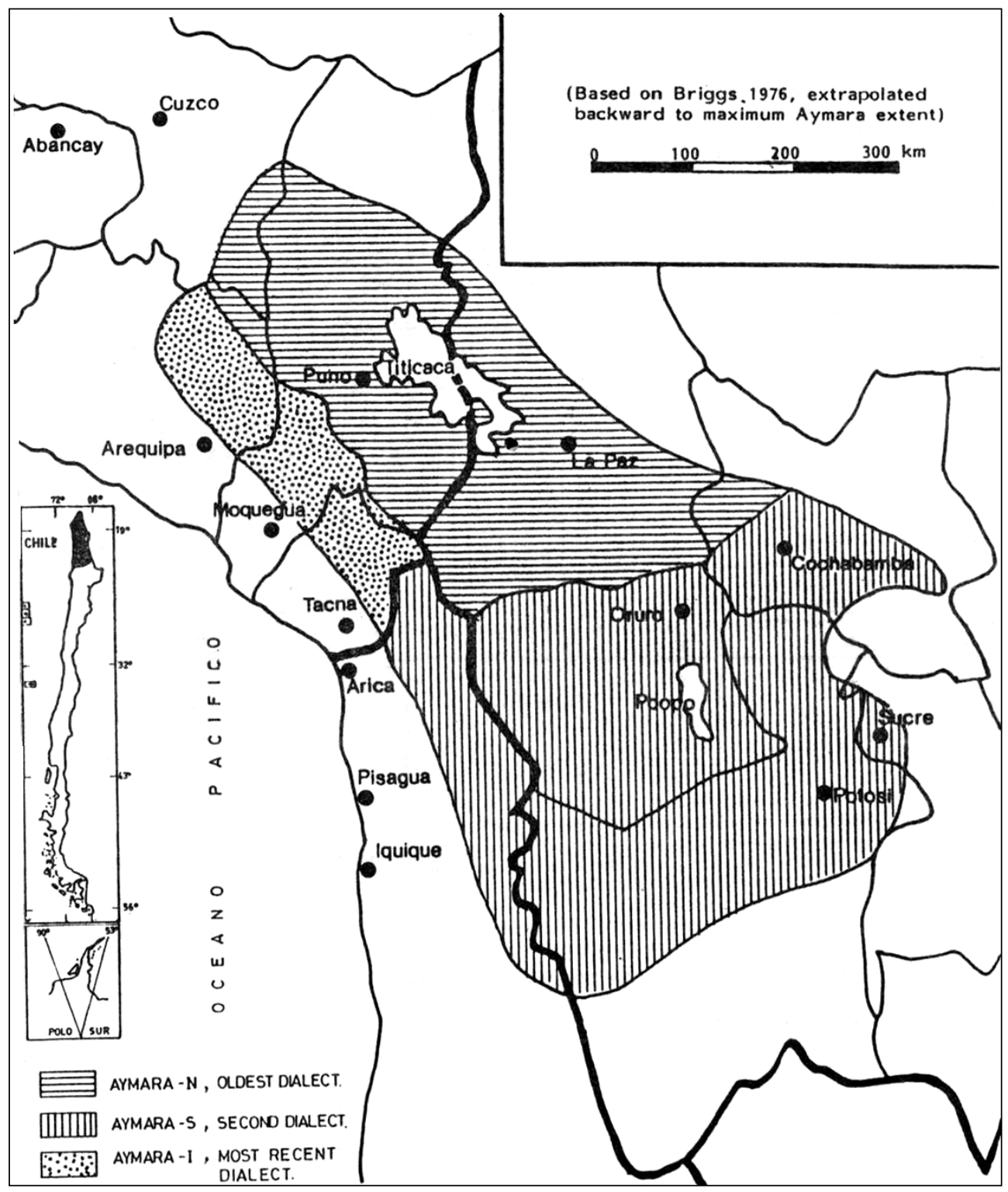

Figura 1. Location of the three major dialects of Aymara reconstructed.

boundaries of the three dialects as reconstructed to ca. AD 1000-1450. The Northern dialect includes large areas of Puno Department in Peru and La Paz Department in Bolivia, and corresponds quite closely to the area defined by Ponce (1980) as the heartland of the Tiwanaku Federation in Tiwanaku III and early IV. The Southern dialect area correlates with the area of expansion of the Tiwanaku Federation during Tiwanaku IV. Thus the Northern dialect can be pushed back to the date of 200 BC-AD 400 in the lake Titicaca Area. The Southern dialect area indicates a spread of Aymara speakers during the AD 375-750 Period.
The third dialect, the intermediate dialect found in the departments of Moquegua, Arequipa, Tacna and south into Arica, relates to two events occurring around AD 800-1000. The first of these is the collapse of the Wari empire in Peru. Recent studies have shown greater contacts between the Tiwanaku federation and the Atarco/Pacheco centers in the Nasca area than even with the Wari highland capital (Browman 1982). The Tiwanaku federation thus may be hypothesized to have had trade relations with the coastal area to secure maize and other coastal products from Wari controlled areas. Wari influence, however, would have prevented the Tiwanaku folk from establishing 
other than trade connections. The collapse of the Wari empire around AD 750-800 would have cut off one necessary supply area and market area for the Tiwanaku people. Note that this collapse of Wari appears to mark the Tiwanaku IV to Tiwanaku V Phase boundary.

During Tiwanaku IV, the Tiwanaku Federation had spread its influence and control into the Cochabamba valley area. Cochabamba was one of the major foodproducing areas of the Inca empire, and also the subsequent Colonial Period, and it served the same function undoubtedly for the Tiwanaku Federation. While Tiwanaku control of Cochabamba appears to continue into the early part of Tiwanaku Phase V, by AD 900 to 1000 the Cochabamba area has clearly separated itself from Tiwanaku control. Cochabamba begins to participate increasingly in other trade networks which tie it in with Southern Bolivia and even as far as the San Francisco Culture area and Quebrada de Humahuaca cultures in Northwest Argentina.

For the Tiwanaku center around lake Titicaca, the critical problem was the loss of two important markets and sources of raw materials at roughly the same time (e.g. about $c a$. AD 800-900). The results of this economic dislocation may be observed in the religious reformulation of Tiwanaku representations in Phase V. Earlier symbolism is greatly changed, and new deities become powerful. During the final Tiwanaku Phase V, which terminate perhaps as late as AD 1250-1300, Tiwanaku compensated for the loss of the Cochabamba and Nasca area markets by adopting a new economic strategy, that of vertical control, with the establishment of Tiwanaku V colonies or mitmaquna in Arequipa, Moquegua, Tacna and Arica. No doubt the collapse of Wari control in the area left a power vacuum which Tiwanaku exploited. There is preliminary evidence, for example, from Cerro Baul in Moquegua which suggests a fortified site first occupied by late Wari empire phases and with apparent subsequent contact with Tiwanaku $\mathrm{V}$ peoples. Whether the Cerro Baul evidence proves out is inconsequential. What is important is that this expansion of Tiwanaku V into Arequipa, Moquegua, Tacna and Arica corresponds with the area of distribution of the "Intermediate" dialect of Aymara (Figure 1).

Thus we appear to be able to correlate the Northern dialect of Aymara with the original growth of
Tiwanaku I-III, the Southern dialect of Aymara with Tiwanaku expansion in Tiwanaku IV, and the Intermediate dialect of Aymara with expansion during Tiwanaku V.

The intrusion of Tiwanaku or altiplano Aymara into coastal areas after the fall of Wari may be our first clear evidence of Tiwanaku militarism. To the north we have already alluded to the fortified site of Cerro Baul in Moquegua. In Northern Chile there is more substantial supporting data. True (1980: 158) reports defensive walls both at Caserones, dated at $\mathrm{AD} 720 \pm 110$ and at Tarapacá $13 \mathrm{~A}$, dated at AD $750 \pm 110$, which fall just at the Tiwanaku IV/V break, and the time of the Wari collapse. Munizaga (1974) reports evidence of a great many more fractures and broken bones in burials at this time, which he sees as an index of confrontation between two cultures, and also believes that there is some evidence for a new physical type.

It has been observed that there is a quite different pattern of Tiwanaku influence in the extreme Northern Chilean area as contrasted to the Loa river and San Pedro de Atacama region. Not only are there different complexes of ceremonial items, but the altiplano items in the Northern area are much more socioeconomic in nature, as contrasted to the larger number of status-validating magic-religious items found in tombs of the elites in places such as San Pedro (see for example Núñez 1964; Berenguer et al. 1980; Serracino 1980).

Though we must be careful not to make overly simplistic correlations between language and culture, use of the linguistic data greatly enhances our reconstructive capabilities. In terms of possible trade relationships that I want to develop for the $\mathrm{AD}$ 1000-1450 Period in the Southern Bolivia Altiplano, I have sketched in the rough areas of some of the more frequently mentioned ethnic groups in the $16^{\text {th }}$ Century (Figure 2). I have focused primarily upon the Southern Altiplano -thus the only group belonging to the Northern Aymara dialect are the Pacajes on this map. The Carangas, Aullaca, and Quillaca are Southern Aymara dialect peoples. In terms of trade relations we subsequently want to discuss, it is important to note that the Chichas area is closely linked linguistically to the Quebrada de Humahuaca, while the Lípez area is linked linguistically to the Atacama region. 


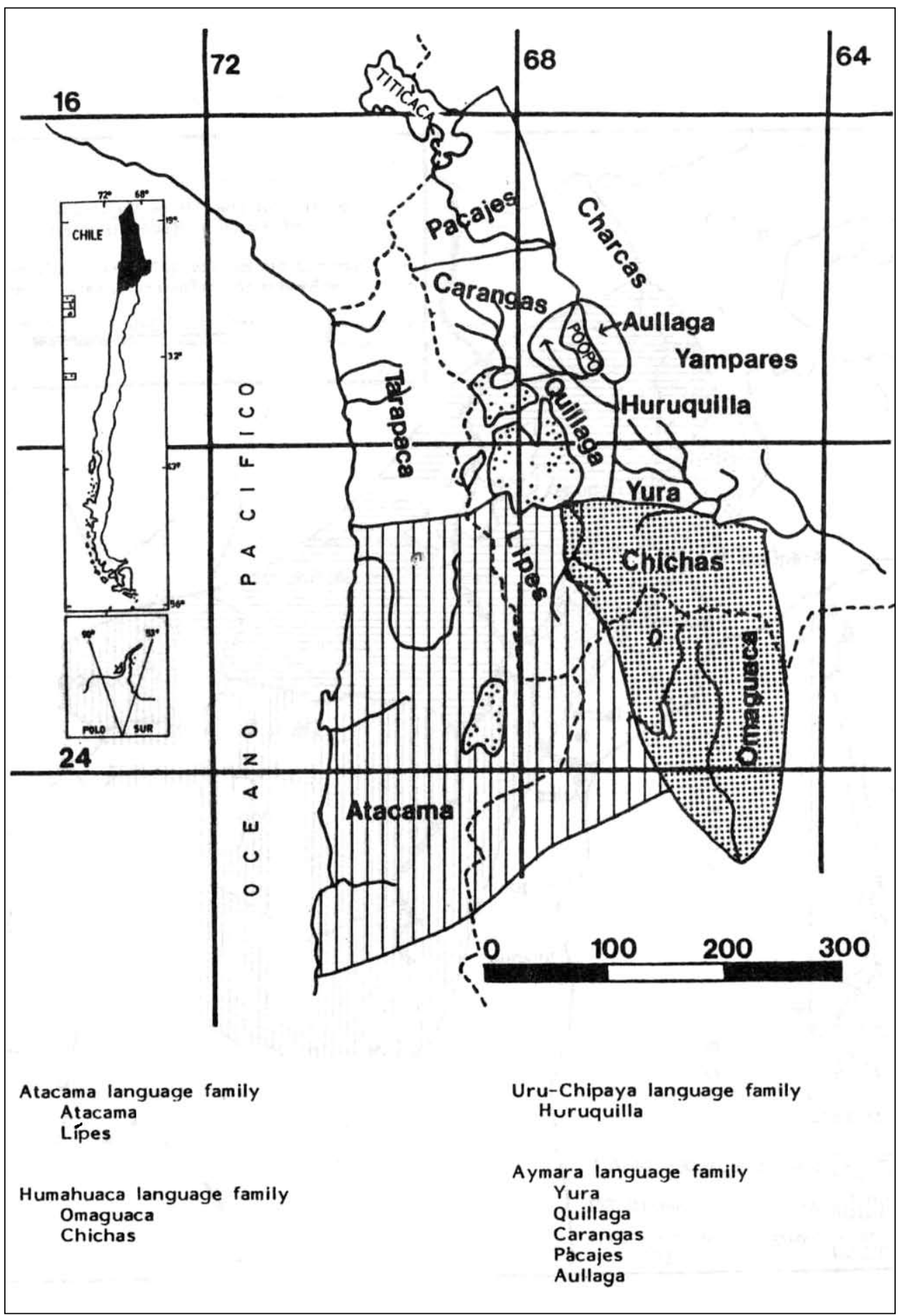

Figura 2.15 ${ }^{\text {th }}$ Century location of major Southern Bolivian ethnics groups. 
Uruquilla or Huruquilla group is a very complex problem. The term "Uru" or "Uruquilla" was utilized in three distinct ways by the Inca and early conquistadores: 1) as a language category, 2) as a tax category, and 3) to designate social status or ethnicity. For example, Browman (1978, 1981a), Julien (1978) and Bittmann (1979) have all argued that the term "Uru" refers to no specific language group, but more frequently to low social status, or occupation. Linguists studying remmant word lists of Uru-Pukina speakers have found relationships for specific "Uru" groups with three different major language families-Penutian, Macro-Chibchan and Arawakan. These are mutually unintelligible languages. It is unfortunate that we have chosen to designate one of the major late ceramic styles in the Southern Altiplano as "Huruquilla" as almost certainly the "Huruquilla" ceramics have no relation to the "Uruquilla" people. The location on Figure 2 simply indicates the area where the Uru-Chipaya of the lake Poopó region were living in the $16^{\text {th }}$ Century. Ceramics for that region are likened to Rydens "Chullpa" style, and have little relationship to any Potosí materials.

The Southern Altiplano group has a number of traits that distinguish them from the Northern group (for example see Vellard 1981). In addition to the language traits and the list by Vellard, we could add economic items such as ch'uño, cochayuyo, and comestible clays (such as p'asa, haq'u or ch'ago). Distribution of certain varieties of the bitter diploid ch'uño potatoes (such as Solanum ajanhuiri; Huaman et al. 1980: 339) are limited to the Northern region. The Northern and Intermediate area are well integrated into the cochayuyo network, while the Southern dialect area is not; the Northern area exploits species quite different than the neighboring Quechua (Masuda 1980: 30). Different comestible clays and earths are traded and consumed in the Northern $v s$. Southern areas. The list goes on, but the point is that the linguistic boundaries do in fact also specify a number of other culture boundaries as well, allowing us a new tool for using ceramics as one of these cultural indicators in reconstructing which specific Aymara groups was in contact with neigh boring Chilean centers.

\section{Auquenid pastoralism and trade}

The bulk of the communities in the Southern Bolivian Altiplano from the Carangas, Aullaga, Quillaca and Lípez area were dependent upon llama and alpaca pastoralism for a major portion of their subsistence.
Although they practiced some agriculture, growing a number of potatoes and other tubers, and Chenopodium grains such as quínoa and cañihua, it was not possible to grow sufficient food to survive. Rainfall is low in this area -in many areas of Southern Oruro and Western Potosí the rainfall is less than $100 \mathrm{~mm}$ annually (as contrasted to $300-600 \mathrm{~mm}$ averages further north, rising to $600-800 \mathrm{~mm}$ in the rain shadow of lake Titicaca). These herding groups exploited four strategies: 1) barter-exchange of the services of llamas as transport animals in adjacent lowland agricultural areas (to bring the harvest, etc.); 2) direct exchange of the herder's labor in lowland agricultural areas for a portion of the harvest; 3 ) direct trade or barter with other communities, using pastoral products such as wool, textiles, etc, or other manufactured goods that they fabricated themselves or obtained in trade along the trade caravan trips; and 4) maintenance of fields through family ties in a variety of vertically stratified ecozones, with reciprocal exchange between relatives of zonal products.

Much of the literature referring to llama caravans in the early colonial epochs for Bolivia focuses upon the mining operations at Potosí. Though this is Spanish rather than Indian in emphasis, it gives useful insights into the general llama caravan functionings of the local herders. Large numbers of llamas and their drovers were involved in the provisioning of Potosí. The altiplano was stripped bare for $40 \mathrm{~km}$ or more around Potosí; thus all firewood, fodder, food and supplies had to be freighted in. More than 800.000 llama loads of taquia were brought in as fuel annually. In the silver production, 18000 llamas were used to bring ore from mine to mill; more than 5000 llamas weres reserved for silver caravans to the coast. Llamas brought in 60000 cestos of coca leaf from Cusco each year (with 3000 to 4000 llamas reserved for this purpose); 200.000 cestos of aji came from Tacna each year; 200.000 bottles of wine come up from the coast each year (requiring another 40006000 cargo llamas), and an additional 40000 llamas were reserved in Potosí for provisioning and another 60000 llamas came with the mitayos each year for their support. Clearly large numbers of llamas and drovers were required (Browman, i.p.). The Lípez groups were apparently excused from working in the mines directly; rather they paid tribute in service as fleteros bringing in large amounts of firewood, and other materials for the center.

Caravans carried a wide assortment of materials: food items, such as maize, potatoes, ch'uño, 
totora, meat, a wide variety of other vegetables and fruits, and even snow; stimulants and drugs, including coca leaf, ayahuasca, chicha, and wine; medicines and remedies, including various altiplano herbs, selva preparations. Pacific coast shells, and medicinal stones (bezoar stones); raw materials and manufactured goods such as cloth, cotton, mercury, gold, copper, silver, ceramics, sandals, and the like; construction materials, such as mine timbers, adobe bricks, and building stone; and fuel and fodder, including tola brush, vareta cushion plants, ichu grass and taquia.

Such caravan activity has continued in the $20^{\text {th }}$ Century. Southern Bolivian herders come down from Lípez area to trade llamas, wool, coca, cane alcohol, incense, candles, musical instruments, various magical stones and medicinal herbs in the San Pedro area for flour, sugar, oil, soap, fruit and some marine products (Krusell 1976; Núñez 1976; Serracino 1980). Herders living near Isluga, Prov. of Tarapaca, Dept. of Iquique, west of the salare of Coipasa, trade eastward into the Chipaya region in Oruro, and also go seasonally (mid-March to mid-September) west down the Andean slopes to graze their flocks and trade for maize (Martínez Soto-Aguilar 1976, 1981).

There are a number of functioning caravan areas in the zone between Potosí and Oruro, caravans from Potosí pass through Huayrapampa, Chuquisaca during the dry season, from June to August, on their way to lower valleys where they trade for corn and aji. At Huayrapampa they trade folk curing items such as llama fat, llama fetuses, altiplano medicinal herbs, and certain compound medicines containing seashells and starfish obtained by trade from the Pacific coast.

From Pampa Aullagas, Ladislao Cabrera Province, Oruro, caravans take salt and highland products (wool, textiles, tubers) eastward to the valleys of Cochabamba, Potosí and Chuquisaca for maize and other valley products (West 1981). In the $19^{\text {th }}$ Century the Pampa Aullagas area also sent caravans to the Chilean coast for such coastal products as cochayuyo (Andrews 1827, 11: 135).

Data is also available on caravans from the macha and laymi groups, east of lake Poopó, about half way between Oruro and Sucre. The macha send caravans out with salt, ch'uño, wool, textiles and clay. The best clay in the area for ceramic comes from the Macha zone. Macha fleteros transport clay on their llamas to Laymi and other areas, and make pots to order (Platt 1976, 1982). The laymi (Harris 1978a, 1978b, 1982; Harris 1978b) formerly relied a good deal more on long distance trade caravans, taking their potatoes, ch'uño, etc., to various areas to trade. They still go east to the valley areas for corn, aji and coca. Until recently they still made the 10 day trip west across the altiplano to help in the grain harvest. In return for their labor, they were paid in quinoa, and acquired additional male llamas from the western group to use as caravan animals.

Additional examples could be provided. I have gone on at some length on the $16^{\text {th }}$ Century and $20^{\text {th }}$ Century trade patterns, as we see the same pattern of exchange of goods and service in both times, and because the llama caravan trade as well as the auchenid pastoralism is basic to the subsistence of the people. Our reconstructions of the groups from the period of AD 1000-1450 assume the same patterns of subsistence to have been true during that epoch.

\section{Tiwanaku-coastal Chile interface}

During the Period of Tiwanaku I/II, I have argued (Browman 1980, 1982) for a new pattern of economic integration emerging on the altiplano. This pattern is a horizontal one and leads to different political and economic institutions than developed in Peru. Tiwanaku achieved ascendancy over a number of regional centers, loosely organized by economic ties. This cluster of regional centers becomes more closely integrated into a federation during Tiwanaku III times primarily because of the validation of Tiwanaku as the political head through its obvious success in missionizing. Religious primacy, as it often has been in archaic state development, thus validates economic and political primacy.

Interaction between Tiwanaku and coastal centers of the confederation appears to be predicated on economic and religious grounds, with little direct political control. Thus the conception of Tiwanaku as a militaristic conquest state like Wari is erroneous. Each separate Tiwanaku-linked center, whether in the Southern Altiplano of Bolivia, on the Chilean coast, interior Chilean valley/oasis area, or in the Northwest Argentine Puna, exhibits a unique assemblage of Tiwanaku-derived materials. Each of these polities maintained sufficient political autonomy that it borrowed or accepted from the Tiwanaku fleteros only those products and ideas which were perceived 
locally to be attractive. There are no massive forts or administrative centers like Pikillacta or Viracocha Pampa in the Tiwanaku sphere of influence. Rather in Northern Chile, for example, items were more socioeconomic in nature, while in San Pedro de Atacama, the items are limited to status validating items for the jefes or elites managed interchange and redistribution.

As noted in our language discussion, there was a dramatic shift in Tiwanaku coastal interchange sometime between AD 750-900. Tiwanaku Phase $\mathrm{V}$ culture now is present in the form of colonists or mitmaquna. The earliest radiocarbon date on this material is $c a$. AD 900-950, and intrusive Tiwanaku $\mathrm{V}$ materials continue until $\mathrm{ca}$. AD 1200-1250. This Tiwanaku $\mathrm{V}$ intrusion may have been associated with military force witness the defensive walls at Caserones and Tarapacá 13A and other evidence referred to earlier.

While Tiwanaku remained as the head of a regional polity in the Titicaca basin for perhaps 400 years after the collapse of Wari, the Tiwanaku confederation itself collapses soon after Wari. The Cochabamba valley area established its independence. The Southern Bolivian Altiplano centers split into a series of regional "kingdoms", and by AD 1000-1250, the Southern Bolivian Complex defined by Yura and Huruquilla ceramics has become the prime Bolivian component of the continuing set of economic networks between Chilean coastal centers, Bolivian altiplano centers, and Northwest Argentina intermountain regional centers.

An historical understanding of the evolution of Tiwanaku influence on the Chilean coast is important for our reconstruction of the period of AD 1000-1450 in the San Pedro -Southern Bolivian Altiplano axis. While San Pedro was never a part of the Tiwanaku network stimulated growth and enhanced the prestige of San Pedro as a political center. Apparent control of certain Tiwanaku-derived goods ultimately traded into Northwest Argentina also enhanced San Pedro economic growth. The Southern Altiplano appears to have been relatively unimport during the period prior to AD 800-1000, but with the collapse of Tiwanaku as the principal altiplano power, there was a growth of importance of the Southern Bolivian Altiplano as a source of altiplano products for San Pedro and possibly Northwest Argentina.

\section{Northern Chilean-Southern Bolivian interchanges $\mathrm{AD}$ 1000-1450}

I see three different patterns of exchange between the Southern Bolivian Altiplano area and adjacent areas of Chile and Argentina. These appear to correlate rather well with the ethnographic boundaries outlined in Figure 2. These can be best summarized by contrasting the evidence from the altiplano and Chilean Region I, the altiplano and Chilean Region II, and the altiplano and Northwest Argentina.

\section{a) Bolivia-Chile (Region I)}

The Region I area north of $19^{\circ}$ Lat. S is involved with trade with the Pacajes and Carangas regions of the altiplano. If the correlations developed to date by scholars such as Focacci (1981) and Trimborn (1975) hold, then the Maytas-Chiribaya ceramics of the Tacna-Arica areas, dating perhaps AD 7501200 , should be contemporary with the Tiwanaku $\mathrm{V}$ mitmaq. I am interested in this area primarily in the later materials, known as Chilpe and Saxamar because ceramics of these latter two types are found further south.

Although Dauelsberg (1960: 290) originally defined the two types as being distinct, they both have been subsumed under the type name Chilpe by some researchers. Particularly diagnostic of the Saxamar was the llamita design; both the Chilpe and Saxamar were primarily black on redware styles. Chilpe/ Saxamar are imitations of, or related to Tschopik's (1946) Collao Black on Red ware and Ryden's (1947) Chullpa ware. Chullpa and Collao ware are particularly diagnostic of the Aymara-the Pacajes, Lupaca and Carangas areas in particular. It is thus no surprise to find such wares reported in a variety of sites in the Arica-Tacna area (for example, Trimborn 1975; Santoro and Muñoz 1981; Lumbreras 197273 , etc.).

Chilpe/Saxamar ware is also found further south. Particularly the the llamita decorated ware is important, as it is spread at least in part by the subsequent Inca conquest. However the llamita design occurs as a popular design during the AD 1250-1450 period in the Northern Altiplano, so one must always use caution in deciding whether the llamita ware is introduced by Inca conquest or is rather possibly a preinca trade item. 
Chilpe/Saxamar ware has been found in Region I further south than $19^{\circ} \mathrm{S}$ latitude. At Sabaipugro, in the lower Camarones area, Chilpe ware is reported associated with an AD 1235 date (Núñez 1976: 122); at Huancarane 3 in Camarones (Niemeyer and Schiappacasse 1981: 27), Chilpe/ Saxamar and llamita ware is found in late contexts; at Isluga (Iquique), Chilpe ware is found in late contexts (Sanhueza and Olmos 1981: 194), and Chilpe ware is found at Pica and Quillagua oases dated roughly AD 1000-1250 (Núñez and Dillehay 1979: 106). At the site of Pica 8, Chilpe ware is associated with a $\mathrm{C}^{14}$ date on a corn cob of AD 1730 \pm 80 (Núñez 1976: 122). Corn, on the average, yields a radiocarbon error of 245 years too recent (Browman 1981b: 271). The Pica 8 date of $\mathrm{AD} 1730$ corrected for this error gives us a date of $\mathrm{AD} 1485 \pm 80$ on Chilpe/Saxamar ware.

Chilpe/Saxamar ware (including llamita ware) is found further south in pre-Inca contexts. Núñez (1968: 174) reports it in association with the Dupont complex in the lower Loa valley at Caleta Huelen area sites and other Loa sites, where it has a date of roughly AD 1300-1500. Llamita ware has been reported from the Middle Loa from the Lasana 4 complex (Pollard 1975) which dates roughly AD 1000-1450. Llamita ware is found east of the Loa area in Bolivia at lake Hedionda sites (Barfield 1961: 99) in preinca assemblages. The occurrence of llamita ware and Chilpe/Saxamar ware at this latitude ( $\mathrm{ca} .22^{\circ}$ to $22^{\circ} 20^{\prime} \mathrm{S}$.) appears to be the result of preincaic trade. Llamita/Chilpe/Saxamar wares are related to the Northern Aymara groups (Lupaca, Pacajes, Carangas), and their occurrence this far south indicates trade between the Aymara area and the Loa river area during a time period of ca. AD 1250-1450.

Llamita ware is found further south as well, into Argentina. For example, Bregante (1926: Figura 350) illustrates an example from the Pucara de Tilcara in Quebrada de Humahuaca, and Pollard (1979b) reports an Inca context llamita ware from La Puerta village, Calchaqui valley, which is identical to his Loa river materials. I assume the llamita ware occurrences in Argentina are all introduced by the Inca conquest, but in light of the occurrence of this material at such sites as lake Hedionda in Southern Bolivia and the Loa river drainage in Region II of Chile during AD 1000-1450, this assumption needs to be tested.

\section{b) Southern Bolivia-Chile (Region II)}

Region II of Chile, particularly the Loa river and San Pedro de Atacama, has yielded a number of examples of late altiplano trade wares. The bulk of theses trade wares appear to have their origins in either the Lípez or the Chichas areas as indicated on Figure 2. Typologically they are usually identified as Huruquilla wares.

Four major late wares have been identified for the Southern Bolivian Altiplano area (Ibarra Grasso 1944, 1953, 1973; Ibarra Grasso and Branisa 1954): Chaqui Yura, Huruquilla and Chichas. Chaqui ware is said to be limited to the Lípez Province areas; it has been found in association with Chilean Rojo Violáceo wares from San Pedro at Calcha, Nor Lípez. Chichas ware is fairly well isolated to eastern Potosí and Tarija in Bolivia. Yura ware and Huruquilla ware were originally defined from sites in eastern and central Potosí; however styles "similar" to these two have been reported for a wide area of Potosí. Without adequate illustrations it is nearly impossible to assess the reliability of all these reports. For example, Barfield's lake Hedionda material (1961: 99) has been called Huruquilla style by some reporters, but a visual inspection of that ware shows no linkage to Huruquilla at all. Rather it is much closer to the Chaqui ware. Ibarra Grasso (1973: 334) thought that the Huruquilla might be a subdivision of the Chichas group. He also identified Huruquilla like materials to the east in the materials excavated by Disselholff at Ida, with radiocarbon dates of AD 950 and AD 1100 (1973: 335). This might suggest that Huruquilla materials are earlier than, and evolve into Yura style materials. Pucher de Kroll (1951: 69) reports Huruquilla materials from San Lucas, Potosí, in direct association with Chaqui ware. The issue is obviously extremely complicated, and we must await excavation of a stratified series of sites to distinguish between Chaqui and Yura/Huruquilla.

We can, however, isolate the general area of occurrence of Chaqui, Yura/Huruquilla and Chichas materials from Northern Aymara styles. Ceramics from the site of Punaca on lake Poopo are similar to Rydén's (1947) Pucara de Khonkho site, which would make them an early version of the Chullpa ware. Materials that I also observed in the Museum in Oruro had a bifold distribution. From the Northern part of Oruro, the late materials were all related to Rydén's Chullpa style. But from the Southern and southeastern areas, the materials were related to Yura/ Huruquilla. Ibarra 
Grasso (1973: 331) has made a similar observation, noting that Yura materials predominate in Southern Oruro. Extremely diagnostic of the late period ceramics is the puco form of bowl, which is found from Southern Oruro south as far as Southern Jujuy in Northwest Argentina. Thus there is a rather sharp cultural boundary between the Southern Aymara groups, and the non-Aymara Lípez and Chichas groups that runs through southern and southeastern Oruro Department. South of this line are found the culture known as Chaqui, Yura, Huruquilla and Chichas. These are the cultures which are seen as having trade relationships with the Loa river and San Pedro de Atacama area during AD 1000-1450. Thus the ethnic groups that San Pedro de Atacama is trading with are not Aymara, and different relationships should be expected to occur.

The Loa river area has a number of close correlations with the ceramics from Lípez provinces of Potosí Department, in addition to some direct trade pieces. Pollard's (1975) Middle Loa river Lasana 4 style, dated AD 1000-1450, is very closely related to Barfield's (1961) lake Hedionda materials. Castro et al. (1979: 49) recognize a Hedionda black on buff ware from Toconce, and suggest it is closely related also to Huruquilla ware. Thus the Loa river to lake Hedionda axis clearly shares some common traits during the AD 1000-1450 Period, with similar local wares being produced from the Middle Loa river to Toconce to lake Hedionda. Actual Huruquilla trade pieces are reported from Caleta Huelen 12 on the Lower Loa river, Dupont 1 on the Middle Loa river, and Toconce to the east of the Loa river (Núñez 1968: 174; Castro et al. 1979: 484). Another vessel, alternately identified as either Yura or Huruquilla, was illustrated from Calama on the Middle Loa river (Boman 1908: 2: Fig. 181).

From San Pedro de Atacama, there are reports of Huruquilla trade wares from Quitor 9, Coyo, Solcor, and Solor 4 (Núñez 1965, 1976, 1978; Tarragó 1968; Le Paige 1976; Serracino 1980). At Quitor 9, tomb 3236, the Huruquilla trade ware is associated with an AD 1050 radiocarbon date. This is similar to the dating for Huruquilla wares at Toconce, where they are associated with radiocarbon dates of AD 1030-1210 (Castro et al. 1979: 492). If the Dupont correlation on the Middle Loa river is correct for Huruquilla, then it may persist as late as AD 1490. This would correlate nicely with Tarragó's (1968: 122) argument for extensive trade between San Pedro de Atacama and Huruquilla/Yura in Bolivia and
Tilcara/Yavi in Argentina between AD 1250-1450. The Huruquilla/Yura trade thus starts no earlier than AD 950-1000, and lasts until the Inca conquest. Present evidence would suggest that the trade patterns remained relatively unchanged during this period, and continued with only minor modification almost up to the $20^{\text {th }}$ Century.

\section{c) Southern Bolivian Altiplano-Northwest Argentina}

The ceramic evidence for interchange between Southern Bolivia and Northwest Argentina suggests the strongest connection between the Jujuy Puna and the adjoining Bolivian Altiplano. Krapovickas (1979: 25) argues for two Jujuy Puna centersCasabindo/Agua Caliente on the west and Yavi Chico on the north. It is Yavi Chico which has the closest relationships with Bolivia. Yavi Chico dates to our AD 1000-1450 Period (radiocarbon dates of AD 930, 1170, 1460; Krapovickas 1979: 20). Yavi Chico polychrome has been illustrated from the sites of Sococha, Artera and Reinecilla in Southern Bolivia by Bregante (1926: 84, 174; Krapovickas 1977: 144). Yavi Chico polychrome has also been found in Inca and early colonial Chichas ethnic group sites (Krapovickas 1977: 144) . It is on this basis that Krapovickas (1977: 30) argues that the Yavi Chico group must be Chichas ethnic group peoples, an assessment in line with Loukotka's (1967) argument that the Chichas and Humahuaca group both spoke the same language. Two artifacts related to llama caravans -the horquetas de atalaje toggles and the tarabitas cinch ropes- are found running from the Yavi Chico and Sansana areas in Argentina north to lake Titicaca during this time period. This indicates that the Yavi Chico area people were involved in the same kind of intensive llama caravan trade as their relations further to the north.

I believe that the Yavi Chico Puna peopole were most likely the caravan mechanism by which Quebrada de Humahuaca materials were traded into both San Pedro de Atacama and Bolivia. Angosto Chico wares from Humahuaca are illustrated by Rosen (1924) from the site of Tolomosa, in Tarija; Angosto Chico materials have also been found in late sites of the San Francisco area east of Humahuaca by Dougherty (Yacobaccio 1980: 14). According to Yacobaccio (pers. comm. 1980) there is a preincaic road which runs from Sococha up to Tarija. Bolivian influence 
in Jujuy is harder to document, but Pérez (1968: 286) reports Huruquilla ware in the Quebrada de Humahuaca, and Ibarra Grasso (1967: 358) reports two pots found in Humahuaca by Serrano as Southern Bolivian imports. Trade between the Southern Bolivian Altiplano and the agricultural areas of the Quebrada de Humahuaca was not as intense as trade to either the east or west, but the pattern we have here is the same pattern which persists into the $20^{\text {th }}$ Century, of Southern Potosí herders seasonally traversing south into Northwest Argentina to secure agricultural products.

Trade via the proposed Humahuaca to Puna de Jujuy to San Pedro area appears to be more intense based on the number of trade items found. Yavi Chico wares have been found in Isla de Tilcara, Angosto Chico and other sites in the Quebrada de Humahuaca; and Tilcara quebrada ware has been found in Yavi Chico sites (Pérez 1973; Krapovickas 1979, 1968; Yacobaccio 1980). Isla quebrada wares have been found in San Pedro at Quitor 5, Quitor 6, Larache, and Tchecar; Tilcara and Yavi ceramics have been found in later San Pedro sites, and San Pedro Negro Pulido has been found up in the Jujuy Puna at Tebenquiche (Tarragó 1968; Pérez 1973; Yacobaccio 1980). This distribution appears to suggest the functioning of the argentine Puna herders as the middlemen or fleteros responsible for the integration between to two lower elevation agricultural areas, San Pedro and Humahuaca. Obviously I have focused here only on ceramics; there are a number of other supporting items, such as the various Pacific coast shells (Concholepas, Pecten, Semele, Oliva sp), foodstuffs, feathers, wood, metal items etc., that flow along these trade networks.

The pattern developed here for Southern Bolivia during the Late Period indicates a much smaller and more mobile population than that reconstructed by Pollard (1979a) for the adjacent agricultural regions of Chile and Northwest Argentina. Nevertheless the Southern Bolivian pastoralists are clearly integrated into the network of exchanges that Pollard hypothesizes for the agricultural areas, and in fact appear to be the prime transport network by which the exchanges take place.

\section{Summary comment}

The combined use of archaeological, linguistic and ethnographic evidence allows us to begin to separate out a group of patterns. On the macro-scale we can now begin to distinguish Aymara ethnic group patterns from those of the Lípez and Chichas ethnic groups of the Southern Altiplano. Within the Aymara area, we can now use the three dialect clusters to help us reconstruct the dynamics of the rise and fall of the Tiwanaku Confederation. In the Southern Altiplano, we can begin to use the linguistic evidence to help sort out the still confused archaeological picture. Evidence indicates that by no later than AD 900-1000, the Southern Bolivian Altiplano was characterized by auchenid pastoralists involved in securing a major portion of their subsistence by trading with lowland agricultural groups, and that this pattern remained relatively unchanged particularly in the Southern Altiplano until historic times.

\section{REFERENCIAS CITADAS}

ANDREWS, J., 1827. Journey from Buenos Ayres in the years 1825-1826. John Murray, Londres.

BARFIELD, L., 1961. Recent discoveries in the Atacama Desert and the Bolivian Altiplano. American Antiquity 27 (1): 93-100.

BERENGUER, J., V. CASTRO y O. SILVA, 1980. Reflexiones acerca de la presencia de Tiwanaku en el norte de Chile. Estudios Arqueológicos 5: 81-94.

BITTMANN, B., 1979. Cobija y alrededores en la época colonial (1600-1750). Actas del VII Congreso de Arqueología de Chile vol. 2, pp. 327-356. Santiago.

BOMAN, E., 1908. Antiquities de la Region Andine de la Republique Argentine et Desert d'Atacama. Imprimerie Nationale, París.
BREGANTE, O., 1926. Ensayo de clasificación de la cerámica del Noroeste Argentino. Buenos Aires.

BRIGGS, L. T., 1976. Dialectal variations in the Aymara language of Bolivia and Peru. Doctoral dissertation, Linguistics, University of Florida.

BROWMAN, D. L., 1978. Toward the development of the Tiwanaku State. En Advances in Andean archaeology, D. Browman (Ed.), pp. 327-349. Mouton, The Hague.

- 1980. Tiwanaku expansion and Altiplano economic patterns. Estudios Arqueológicos 5: 107-120.

1981a. New light on Andean Tiwanaku. American Scientist 69 (4): 408-419.

1981b. Isotopic discrimination and correction factors in radiocarbon dating. En Advances in archaeological method 
and theory, M. Schiffer (Ed.), 4: 241-295. Academic Press, Nueva York.

1982. Some political and economic implications of the Wari-Tiwanaku interface. $44^{\text {th }}$ International Congress of Americanists, Manchester.

En prensa. Llama caravan fleteros and their importance in production and distribution. En Nomads in a changing world, P. C. Salzman y J. G. Galaty (Eds.). ISHI, Filadelfia.

CASTRO, V., J. BERENGUER, C. ALDUNATE, S. GODOY y C. GOMEZ, 1979. Antecedentes de una interacción altiplanoárea atacameña durante el Período Tardío: Toconce. Actas del VII Congreso de Arqueología Chilena vol 2, pp. 477-498. Ediciones Kultrún, Santiago.

DAUELSBERG, P., 1960. Contribución al estudio de la arqueología del valle de Azapa. En Antiguo Perú: Espacio y tiempo, R. Matos (Ed.), pp. 273-296. Mejía Baca, Lima.

FOCACCI, G., 1981. Nuevos fechados para la época de Tiahuanaco en la arqueología del norte de Chile. Chungara 8: 63-78.

HARRIS, O., 1978a. El parentesco y la economía vertical en el ayllu laymi, norte de Potosí. Avances 1 (1): 51-64.

_ 1978b. Kinship and vertical economy of the laymi ayllu, norte de Potosí. Proceedings of the $42^{\text {nd }}$ International Congress of Americanists vol. 4, pp. 165-177.

1982. Labor and produce in an ethnic economy, Northern Potosí, Bolivia. En Ecology and exchange in the Andes, D. Lehmann (Ed.), pp. 70-96. Cambridge University Press, Cambridge.

HUAMAN, Z., J. G. HAWKES y P. R. ROWE, 1980. Solanum ajanhuiri: An important diploid potato cultigen in the Andes. Economic Botany 34 (4): 335-343.

IBARRA GRASSO, D., 1944. Las ruinas y la cultura de los yura. Revista Geográfica Americana 11 (127): 208-212.

1953. New archaeological cultures from the departments of Chuquisaca, Potosí and Tarija, Bolivia. American Antiquity 19 (2): 126-129.

_ 1967. Argentina indígena y prehistoria americana. Tipográfica Editora Argentina, Buenos Aires.

_ 1973. Prehistoria de Bolivia (2ª edición). Editorial Los Amigos del Libro, La Paz.

IBARRA GRASSO, D. y L. BRANISA, 1954. Nuevos estilos en la cerámica indígena de Bolivia. Proceedings of the $31^{s t}$ International Congress of Americanists vol 2, pp. 727-760. São Paulo.

JULIEN, C. J., 1978. Inca administration in the Titicaca Basin as reflected at the Provincial Capital of Hatungolla. Doctoral Dissertation, Anthropology, University of California, Berkeley.
KRAPOVICKAS, P., 1968. Subárea de la Puna argentina. Proceedings of the $37^{\text {th }}$ International Congress of Americanists vol 2, pp. 235-271. Buenos Aires.

- 1977. Arqueología de Cerro Colorado, Departamento Yavi, Provincia de Jujuy, República Argentina. Obra del Centenario del Museo de La Plata 2: 123-148.

1979. Relaciones entre la Puna y zonas vecinas a través de su borde oriental. $43^{\text {rd }}$ International Congress of Americanists, Vancouver.

KRUSELL, H., 1976. Artesanos y artesanías de los pueblos precordilleranos de la zona circundante al Salar de Atacama. Estudios Atacameños 4: 131-144.

LE PAIGE, G., 1976. Introducción al trabajo de la Dra. Myriam Tarragó de Font. Estudios Atacameños 4: 35-36.

LOUKOTKA, C., 1967. Ethnolinguistic distribution of South American indians. Annals of the American Association of Geographers 57 (2): Map 8.

LUMBRERAS, L., 1972-73. Carta sobre la problemática arqueológica de Arica. Chungara 1-2: 25-27.

MARTINEZ SOTO-AGUILAR, G., 1976. Características de orden antropológico y socioeconómico de la comunidad de Isluga. Norte Grande 1 (3-4): 403-426.

- 1981. Los aymara chilenos. En Acerca de la historia y el universo aymara, pp. 35-42. Centro de Información, Estudios y Documentación, Lima.

MASUDA, S., 1980. Interregional relationships in Southern Peru: Maritime activities of highlanders in three Southern Departments of Arequipa, Moquegua and Tacna. Bulletin of the National Museum of Ethnology 1 (2): 1-43.

MUNIZAGA, J., 1974. Paleopatología chilena. Antropología 1: 35-39.

NIEMEYER, H. y V. SCHIAPPACASSE, 1981. Aportes al conocimiento del Período Tardío del extremo norte de Chile: Análisis del sector Huancarane del valle de Camarones. Chungara 7: 3-103.

NUÑEZ, L., 1964. Problemas en torno a la tableta de rapé. Anales de la Universidad del Norte 2: 149-168.

1965. Desarrollo cultural prehispánico del norte de Chile. Estudios Arqueológicos 1: 37-85.

— 1968. Subárea Loa-costa chilena desde Copiapó a Pisagua. Proceedings of the $37^{\text {th }}$ International Congress of Americanists vol 1, pp. 145-182. Buenos Aires.

_ 1976. Registro regional de fechas radiocarbónicas del norte de Chile. Estudios Atacameños 4: 74-123.

1978. Northern Chile. En Chronologies: New World archaeology, R. Taylor y C. Meighan (Eds.), pp. 483-512. Academic Press, Nueva York. 
NUÑEZ, L. y T. DILLEHAY, 1979. Movilidad giratoria, armonía social y desarrollo en los Andes Meridionales: Patrones de tráfico e interacción económica (ensayo). Universidad del Norte, Antofagasta.

PEREZ, J. A., 1968. Subárea de Humahuaca. Proceedings of the $37^{\text {th }}$ International Congress of Americanists vol 1, pp. 273-294. Buenos Aires.

1973. Arqueología de las culturas agroalfareras de la Quebrada de Humahuaca (Provincia de Jujuy, República Argentina). América Indígena 33 (3): 667-679.

PLATT, T., 1976. Espejos y maíz: Temas de la estructura simbólica andina. Cuadernos de Investigación CIPCA 10.

1982. The role of the Andean ayllu in the reproduction of the petty commodity regime in Northern Potosí. En Ecology and exchange in the Andes, D. Lehmann (Ed.), pp. 27-69. Cambridge University Press, Cambridge.

POLLARD, G., 1975. Prehistory and desert adaptation in Northern Chile: The ceramic state of the Middle Rio Loa Region. Part 1; Settlement and ecology. SUNY Press, Albany.

_ 1979a. Interregional relations in the Southern Andes: Evidence and expectations for understanding the late prehistory of NW Argentina and N Chile. $43^{\text {rd }}$ International Congress of Americanists, Vancouver.

1979b. Excavations in the Borgatta village site, Calchaqui valley, Argentina. St. Louis.

PONCE, C., 1980. Panorama de la arqueología boliviana. Librería y Editorial Juventud, La Paz.
PUCHER DE KROLL, L., 1951. La cerámica zoomorfa de los Uruquillas-Yamparez-Kollas de las regiones de Potosí, Chuquisaca y Tiahuanaco. Universidad 14 (32-34): 62-79.

RYDEN, S., 1947. Archaeological researches in the Highlands of Bolivia. Elanders Bolktryckeri Aktieborg, Gotemburgo.

SANHUEZA, J. y O. OLMOS, 1981. Usamaya I, cementerio indígena en Isluga, altiplano de Iquique, I Región, Chile. Chungara 8: 169-207.

SANTORO, C. e I. MUÑOZ, 1981. Patrón habitacional incaico en el área de Pampa Alto Ramírez, Arica, Chile. Chungara 7: 144-171.

SERRACINO, G., 1980. Tiwanaku desde San Pedro de Atacama. Estudios Arqueológicos 5: 95-106.

TARRAGO, M., 1968. Secuencias culturales de la etapa agroalfarera de San Pedro de Atacama. Proceedings of the $37^{\text {th }}$ International Congress of Americanists vol 2, pp. 119145. Buenos Aires.

TRIMBORN, H., 1975. Los valles de Caplina y Sama. En Investigaciones arqueológicas en los valles del Caplina y Sama, H. Trimborn, O. Kleemann, K. J. Narr, W. Wurster (Eds.), pp. 13-60. Antropos-Institut. St. Augustin Bei, Bonn.

TRUE, D., 1980. Archaeological investigations in Northern Chile: Caserones. En Prehistorics trails of Atacama: Archaeology of Northern Chile, C. Meighan y D. True (Eds.), pp. 139178. Monumenta Archaeologica 7, University of California, Los Angeles.

VON ROSEN, E., 1924. Popular account of archaeological research during the swedish Chaco-Cordillera expedition 1901-1902. Alb. Bonniers Boktryckeri, Estocolmo. 